\title{
Deus o Ressuscitou dos Mortos
}

\author{
God raised him from the dead
}

Dom Paulo Cezar Costa

\section{Resumo}

A ressurreição de Jesus é a afirmação central da Fé cristã. Neste artigo, trata-se da ressurreição de Jesus, vendo-a como obra de Deus sobre Jesus. Não se trabalha todos os textos sobre a ressurreição, mas se detém na narrativa de São Paulo em 1Cor 15, 3-7 e nos textos dos Evangelhos sinóticos sobre o sepulcro vazio e as aparições do ressuscitado. Não se ignora que por detrás de um texto existe uma tradição presente e que, por isso, a narrativa parte de um Evento que é comunicado com a finalidade kerymática e catequética. Faz-se um diálogo com as principais posturas exegéticas e teológicas. Conclui-se, a partir do material analisado, com algumas afirmações fundamentais para a fé na ressurreição de Cristo.

Palavras-chave: Ressurreição de Jesus. Sepulcro vazio. Aparições do Ressuscitado. Fé cristã. Cristologia.

\begin{abstract}
The resurrection of Jesus is the central confirmation of the Christian faith. In this article, the aim is to treat the resurrection of Jesus as the work of God on Jesus. It is not worked on all the texts about the resurrection, but, on the other hand, there is emphasis on the narrative of Saint Paul in 1Cor $15,3-7$ of the synoptic Gospels about the empty tomb and the appearances of the resurrected. It is not ignored, though, that behind a text there is a present tradition and because of that, the narrative starts with an Event which is told with a kerygmatic and catechetical goal. A dialog is stablished with the main
\end{abstract}


exegetical and theological positions. Some fundamental affirmations to the faith in the resurrection of Christ are concluded considering the material which has been analysed.

Keywords: Resurrection of Jesus. Empty Tomb. Appearances of the Risen One. Christian faith. Christology.

\section{Introdução}

Entre a morte de Jesus e a primeiríssima pregação dos seus discípulos, do ponto de vista histórico, há um non sequitur, um abismo aparentemente intransponível. A fé cristológica do cristianismo primitivo jerosolimitano não nasceu da morte de Jesus, pois sua morte foi do tipo ignominioso, mas também a idéia de um Messias sofredor era estranha à mentalidade judaica. $\mathrm{O}$ fato de que este abismo tenha sido superado por alguns judeus, discípulos do nazareno, exigem uma explicação que seja proporcional ao abismo intransponível. Já o protestante racionalista David Friedrich Straus admitia: "A formidável reviravolta (der ungeheure Umschwung), que, da profunda depressão e total desespero causado pela morte de Jesus, levou à força da fé e ao entusiasmo com que os discípulos o anunciaram como Messias, não se poderia explicar se no tempo intermediário não produzisse um acontecimento excepcionalmente encorajador"1. O cristianismo primitivo fundava sua fé não sobre uma reconstrução científica do Jesus histórico, mas na escuta da viva proclamação dele morto e ressuscitado. Somente a experiência pascal poderia consentir nos discípulos o nascimento de uma reflexão de fé, que se pode chamar propriamente cristologia.

O primeiro grande anúncio da comunidade primitiva descreve a Ressurreição como ação de Deus sobre Jesus de Nazaré: Deus o ressuscitou dos mortos (At 2,24; 3,15; 4,10; At 5,30; 10,40; 13,30; 1Cor 6,14; 15,15; Rm 10,9). Nestes textos, subjaz uma fórmula fixa: Deus o ressuscitou dos mortos. Esta fórmula de fé é considerada o credo mais antigo. Ela está em relação com a fé na ressurreição dos mortos, isto é, a ressurreição universal, crida por muitos judeus, que era esperada para o fim dos tempos. Jesus foi ressuscitado dos mortos por Deus. A ressurreição universal se adiantou em

\footnotetext{
${ }^{1}$ STRAUSS, D. F. Das Leben Jesu kritisch bearbeitet. Volume II. Tübingen: Mohr, 1836, pp. 631-632.
} 
Jesus: Nele se cumpre e com ele começa o final dos tempos. Esta fórmula é uma afirmação sobre Deus e sua ação ${ }^{2}$. $O$ fato da ressurreição não vem nunca descrito na sua factualidade, porque não teve nenhuma testemunha ocular. O Novo Testamento traz as narrações referentes ao sepulcro vazio e as aparições do ressuscitado.

Neste artigo, queremos tratar a ressurreição de Jesus a partir da narrativa de Paulo em 1Cor 15, 3-7 e das narrativas sobre o sepulcro vazio e as aparições do ressuscitado dos Evangelhos sinóticos, mas fazê-lo em diálogo com a exegese e com a teologia. Queremos perceber a influência das diversas tendências exegéticas e sistemáticas na reflexão sobre a ressurreição de Jesus.

\section{O Evangelho de São Paulo sobre a Ressurreição}

A narrativa de 1 Cor 15, 3-8 é o testemunho mais antigo sobre a ressurreição de Jesus. A epístola de São Paulo aos Coríntios data entre os anos 54 e 57 da era cristã. Esta fórmula é pré-paulina ${ }^{3}$. Entre os fiéis da Igreja de Corinto surgiram algumas questões sobre a ressurreição dos mortos e o apóstolo. Para fundamentar o discurso sobre a ressurreição dos mortos, parte da ressurreição de Cristo.

Paulo diz que transmitiu o que ele mesmo recebeu. Os verbos paradidonai / paralambanein "transmitir/receber", que correspondem àquela hebraica masar / qibbel, remetem à comunicação tradicional. Paulo precisa que transmitiu as coisas essenciais, de primeira importância ${ }^{4}$. Porém, mostra que ele é um elo da Tradição que o precede e da qual ele depende.

Foi sepultado - O credo primitivo fala da sepultura de Jesus como de um acontecimento que seguiu a sua morte. A estrutura do texto liga a sepultura à morte que a precede, como sua confirmação conclusiva. Paulo, ligando a sepultura com a morte, pretende explicitamente ratificar o fato de uma morte certa. Porém, considerando não mais a morte que o precede, mas a ressurreição que o segue, agora não há dúvida, que pelo menos de modo implícito, é compreendido o tema do sepulcro vazio. O uso de etafe no Antigo Testamen-

\footnotetext{
${ }^{2}$ EYZAGUIRRE, S. F. Jesùs. Los orígenes históricas del cristianismo: desde el año 28 al 48 d.c. Santiago: Ediciones Universidad Católica de Chile, 2007, p. 100.

${ }^{3}$ THEISSEN, G.; MERZ, A. O Jesus histórico. Um manual. São Paulo: Edições Loyola, 2002, p. 515, comenta: "sua origem pré-paulina é certa, ela é mais antiga que a comunidade de Corinto, que supostamente foi fundada por volta de 49/50".

${ }^{4}$ FABRIS, R. Prima Lettera ai Corinzi. Milano: Paoline, 1999, p. 199.
} 
to, na LXX, sempre se refere ao fato concreto e individual de um sepultamento determinado (Gn 35,8; Jd 8,32; 12,7.10.12; Dt 10,6; 1Rs 2,10; 11,43...). A expressão é sempre seguida por determinações sobre o local ou pelo menos sobre referência concreta sobre o túmulo ou o motivo da sepultura ${ }^{5}$. No texto de At 13, 29 é claramente enunciada uma tradição sobre a sepultura de Jesus. Do texto de At 2, 29 se pode deduzir a sepultura de Jesus, pois o argumento não se imporia sem a existência do túmulo de Jesus, pois o túmulo de Davi estava em Jerusalém e era conhecido (F. José, Ant. 7, 392-394). A ligação do argumento com o Salmo 16, texto fundamental na pregação primitiva, depõe a favor da sua antiguidade. A expressão conserva o seu valor bem determinado e concreto. Deve-se considerar ainda que, segundo a mentalidade e a antropologia judaica, seria impossível falar da ressurreição sem que o ressuscitado tenha primeiro saído do sepulcro ${ }^{6}$. A ressurreição mesma é concebida como um abandono do sepulcro (Mt 27,53). Então, proclamar a ressurreição implica o acontecimento do sepulcro vazio.

Ressuscitou - $\mathrm{O}$ verbo egegertai tem uma riqueza de significado. $\mathrm{O}$ tempo do verbo é perfeito. A ação é apresentada como continuada. A ação de Deus no ressuscitar Jesus prossegue ainda nos seus efeitos. Aquele que foi ressuscitado continua vivo no presente. O verbo egeiro é usado no seu significado genérico. Este verbo tem o significado genérico de acordar do sono, levantarse. A morte apresentada como acordar do sono, é presente no Novo Testamento (Mt 9,24; Jo 11,11; 1Ts 4,15). Assim, egeiro é usado em sentido metafórico de retorno do sono (Mt 9,25; Lc 7,14; Jo 12,1). Este mesmo verbo, aplicado à ressurreição de Jesus, acentua mais o seu aspecto metafórico. Não se trata de um retorno à vida terrena, como no caso do filho da viúva de Naim e de Talita. A ressurreição, no caso de Jesus, manifesta uma vida que não terminará, implica uma vitória definitiva sobre a morte ( $\operatorname{Rm} 6,9)$. A vida que se manifesta na ressurreição não é como a mesma de antes; não será mais um corpo phisikon. Cristo terá com a ressurreição um corpo pneumatikon, espiritual, vivificado pelo pneuma como princípio de vida superior, celeste $(1 \text { Cor } 15,44)^{7}$.

\footnotetext{
${ }^{5}$ MARTINI, C. M. Il problema storico della risurrezione negli studi recenti. Roma: Universitá Gregoriana Editrice, 1980, pp. 79-80.

${ }^{6}$ KREMER, J. Das älteste Zeugnis Von der Auferstehung Christi. Eine bibeltheologische Studie zur Aussage und Bedeutung Von 1Kor 15, 1 -11. Volume 17. Katholisches Bibelwerk: Stuttgart, 1966, p. 3; RIGAUX, B. Dieu l'a ressuscite. Exégèse et théologie biblique. Gembloux: Duculot, 1973, p. 123; DÍEZ MACHO, A. La resurreccion de Jesucristo y la del hombre. Madrid: Editorial Fondacion Ross, 1977, p. 270.

${ }^{7}$ CABA, J. Cristo mia speranza è risorto. Cinisello Balsamo: Edizioni Paoline, 1988, p. 119.
} 
A expressão terceiro dia, nas cartas de Paulo, se encontra somente neste texto. Este texto recolhe uma tradição que terá um grande eco no Novo Testamento (At 10,40; Lc 24,7.21.46). Paulo, quando explicita o "terceiro dia", une a expressão aos dados da morte e sepultura que, como evidente acontecimento histórico, aconteceu num tempo concreto. Parece razoável que este dado temporal, "terceiro dia" tenha um significado cronológico real. Determinar qual a duração cronológica deste tempo é um problema diverso. Parece razoável que, na nota temporal de São Paulo, tenha um verdadeiro dado cronológico, calculado como três dias ${ }^{8}$.

Apareceu - Na estruturação do conjunto, o verbo confere clareza à ressurreição, como a sepultura confirma o fato da morte. O mesmo termo usado neste texto, $̋ \emptyset \tau \eta$, se encontra muitas vezes no Antigo Testamento e no Novo Testamento, para narrar as diversas aparições: Abraão (Gn 12,7; [At 7,2]; 18,1; 26,2.26), Jacó (Gn 35,9), Moisés (Ex 3,2.6). Os Evangelhos narram ao mesmo tempo as aparições de anjos: a Zacarias no templo (Lc 1,11) e a Jesus na oração do Horto das Oliveiras (Lc 22,43). Moisés e Elias, na transfiguração, vem apresentado do mesmo modo (Mt 17,3; Mc 9,4). Esta será uma fórmula como que consagrada para acenar a experiência de Paulo em Damasco (At 13,31; 26,16) e aos discípulos (Lc 24,34). No credo primitivo são colocados em linha de continuidade, mediante o mesmo verbo $̋ \phi \tau \eta$, São Paulo e os outros discípulos aos quais aparece Cristo.

$\mathrm{Na}$ construção, o verbo tem o sentido da voz média: Cristo aparece, se manifesta. A iniciativa provém dele, o agir dos discípulos se limita simplesmente a gozar da oportunidade que vem oferecida a eles. O significado da iniciativa de Cristo que se manifesta é em harmonia com o uso freqüente deste verbo na sua aplicação a Deus. O significado teológico é mostrar Deus que, saindo do seu mistério, faz-se presente àquele ao qual se revela. Nas aparições, é Cristo ressuscitado mesmo que desvela a sua nova forma para comunicar-se com aqueles aos quais se mostra.

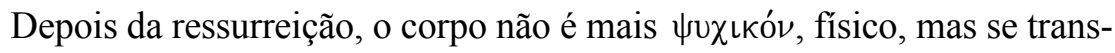

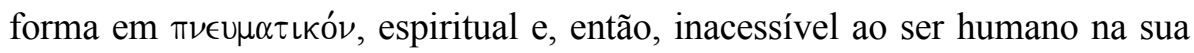
realidade íntima (1Cor 15,44). Na realidade, nas aparições recordadas por Paulo e desenvolvidas depois nos Evangelhos, há sempre algo que supera o simples ver sensível. A experiência de Paulo, o seu $̋$ $\phi \tau \eta$, será considerado como revelação que Deus lhe fez do seu Filho $(\mathrm{Gl} 1,16)$. As aparições aos apóstolos,

${ }^{8}$ CABA, J. Cristo mia speranza è risorto, p. 121. 
as quais apresentam certa uniformidade com a experiência de Paulo, são assinaladas deste significado de revelação e de penetração de Jesus na realidade mais íntima, pois terminam crendo. As narrações dos Evangelhos terão sempre um aspecto de revelação verbal, distinto das aparições. Porém, pela presença de uma revelação que acompanha sempre as aparições, estas não constituem um fenômeno puramente subjetivo. Realmente, quando Paulo enumera as suas diversas experiências místicas (2Cor 12,1-4), não acena a quanto aconteceu em Damasco. Quando se referem à aparição do ressuscitado tida pelo apóstolo, os textos excluem qualquer elemento que possa sugerir uma nota de subjetividade, como seria aquela de uma visão tida em sonho durante a noite (At 16,9; 18,9), ou numa situação de êxtase (At 22,17). Quando Paulo fala do acontecimento de Damasco, o contexto contribui para sublinhar algo que supera a simples subjetividade, enfatizando o âmbito do que acontece fora da pessoa, a objetividade. Assim, Paulo fala da aparição a ele, numa linha de continuidade com a morte, sepultura e ressurreição de Cristo. Também as aparições aos apóstolos, alinhadas com aquela de Jesus a Paulo, comunicam-lhe um caráter de encontro real com o ressuscitado que distingue as narrações transmitidas pelos Evangelhos. A natureza destas aparições é algo que foge às nossas categorias. De uma parte, não se trata puramente de visões subjetivas. Na aparição entra em jogo o encontro com o ressuscitado, colocado numa linha de continuidade com Aquele que morreu e foi sepultado. Não se trata de uma visão meramente sensível como aquela de qualquer outro corpo. Encontramos-nos com uma forma paradoxal de falar, na qual convergem elementos desiguais como a revelação que provém em última instância de Deus e a percepção corporal de algo que supera a capacidade mesma da visão humana.

O credo primitivo da comunidade faz menção da existência de testemunhas que, manifestando o seu encontro com o ressuscitado, atestam que Deus o ressuscitou (1Cor 15,15). A tradição inicial, na qual é inserida a aparição a Cefas e aos Doze, vem ampliada por Paulo mediante o acréscimo de outras tradições sobre a aparição a mais de quinhentos irmãos, a Tiago, a todos os apóstolos e a ele mesmo?.

A finalidade da enumeração destas testemunhas é aquele de mostrar a credibilidade daquilo que já foi aceito na fé: a ressurreição de Cristo. As tes-

\footnotetext{
${ }^{9}$ Xavier Leon-Dufour trabalha com a hipótese de duas tradições sobre as aparições: uma surgida em Jerusalém e outra na Galiléia. Para ele, a tradição de Jerusalém é a mais antiga e terá influenciado Paulo (LÉON-DUFOUR, X. Risurrezione di Gesù e messaggio Pasquale. Cinisello Bolsamo (Milano): Edizione Paoline, 1987).
} 
temunhas da ressurreição de Cristo são reunidas em quatro grupos, mediante a

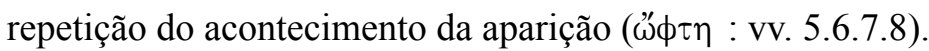

\subsection{Cefas e os Doze}

Paulo inicia com Cefas. Este foi o nome que Jesus conferiu a Simão, filho de João (Jo 1,42). A aparição de Jesus a Pedro é um dado que se repete na tradição Evangélica: é preanunciado no Evangelho de Marcos $(16,7)$ e é confirmado por Lucas $(24,34)$. O texto de Paulo, como aquele dos Evangelhos, nada dizem de concreto sobre o tempo, lugar ou sobre a forma da aparição. $\mathrm{O}$ fato de que se inicie por ela, atesta a sua importância para a Igreja primitiva; isto é confirmado pela narração de Lucas: "o Senhor verdadeiramente ressuscitou e apareceu a Simão" (Lc 24,34).

Paulo menciona, ao lado da aparição a Cefas, aquela aos doze, distinguindo-a da primeira pelo advérbio $[\epsilon i \tau \tau]$, depois. É uma única vez que Paulo menciona o grupo dos doze. Este grupo tem as suas raízes na eleição que Jesus mesmo fez de doze dos seus discípulos, chamando-os de apóstolos (Mt 10, 1-2; Mc 6, 13; Lc 9,1). A tradição, que se refere ao período entre a morte e ressurreição de Jesus e a eleição de Matias (At 1,15-16), fala do grupo dos onze (Mt 28,16; Mc 16,14; Lc 24, 9.33; At 1,16). Esta denominação de onze, não se explicaria se os doze não tivessem as suas raízes na vida de Jesus. Paulo aqui, acena ao grupo oficial dos "Doze" diminuído já por causa de Judas, o traidor (Mc 14, 10.20) e completado por Matias (At 1,26). Nem Paulo precisa os detalhes desta aparição de Jesus ao grupo oficial dos discípulos; os Evangelhos narram-nas (Mt 28,16; Lc 24,36-49; Jo 20,19-29).

\subsection{Mais de quinhentos irmãos}

Um grupo de mais de quinhentos irmãos de uma vez constitui o segundo grupo enumerado por Paulo. Todos aqueles que assistiram a esta aparição são denominados como irmãos $\alpha \dot{\delta} \in \lambda \phi o i \varsigma$. Esta denominação é freqüente nas cartas de Paulo para indicar todos aqueles que abraçam a fé (1Cor 1,10.11.26; 2,1; $3,1 ; 4,6 ; 7,29 ; 10,1 ; 12,1 ; 14,6.20 .26 .39)$. Também aqui não se faz menção das circunstâncias concretas, porém se mencionam alguns detalhes que podem ser significativos. O primeiro é a menção de mais de quinhentos irmãos aos quais vem a aparição, a todos simultaneamente $(\epsilon \phi \alpha \dot{\pi} \pi \alpha \xi)$. Nem os Evangelhos nem o livro dos Atos mencionam esta aparição. A circunstância do número extraor- 
dinário de testemunhas nesta aparição e o fato de que Jesus tenha aparecido a todos juntos sublinham a credibilidade do fato. Um outro detalhe importante é a afirmação de que "a maioria dos quais ainda vive". O ainda de São Paulo se refere à época em que ele escreveu a carta, isto é, pelos anos 54-57. Cerca de 20 anos após a aparição vivem ainda muitas testemunhas.

\subsection{Tiago e todos os apóstolos}

O terceiro grupo é composto por Tiago e todos os apóstolos. O nome de Tiago, sem maiores referências, se refere àquele que é chamado pela primeira comunidade primitiva como chefe dos cristãos provenientes do judaísmo na cidade de Jerusalém (At 12,17; 15,13; 21,18). O seu lugar de relevância (G1 $2,12)$ vem do fato que em algumas circunstâncias ele é chamado "irmão do Senhor" (Gl 1,19) e vem chamado junto com Pedro e João "coluna da Igreja" (G1 2,9). Não conhecemos nenhum detalhe desta aparição nem dos Evangelhos nem dos Atos dos Apóstolos.

Neste grupo vêm mencionados os chamados "apóstolos". O termo apóstolo geralmente vem aplicado ao grupo dos "Doze" (Mt 10,2; Mc 6,30; At 1,26), porém há uma projeção maior: Paulo chama a si mesmo apóstolo, mesmo sem pertencer ao grupo dos Doze. Paulo ainda aplica este denominativo a colaboradores seus Andrônico e Júnia (Rm 16,7), a Epafrodito (F1 2,25) e em geral a outros $(2$ Cor 8,23$)$. Por isso, quando Paulo fala de "aparição" a todos os apóstolos, refere-se a um grupo de seguidores de Jesus Cristo difícil de precisar, porém mais amplo que aquele dos doze.

\subsection{Paulo}

O testemunho autobiográfico de Paulo constitui o quarto grupo que garante a aparição do ressuscitado. Colocar-se no final, pode significar que Paulo se sente o último dos apóstolos ou, ainda, exprimir um dado cronológico que fecha todas as aparições. Em outros momentos, Paulo acena a este dado da sua vida, considerado sob o aspecto de revelação $(\mathrm{Gl} 1,16)$ ou de visão (1Cor 9,1). A expressão "apareceu também a mim como a um abortivo" é uma expressão forte e que acena a esta experiência do apóstolo ${ }^{10}$.

\footnotetext{
${ }^{10}$ LÉON-DUFOUR, X. Risurrezione di Gesù e messaggio Pasquale. Cinisello Bolsamo (Milano): Edizione Paoline, 1987, p. 117, comenta que a aparição a Paulo é idêntica em substância às aparições narradas nos Evangelhos.
} 


\section{A mensagem de Marcos sobre a Ressurreição de Jesus: Mc 16,1-8}

A parte inicial do último capítulo do Evangelho de Marcos (16,1-8) está unida a quanto a precede. A narração sobre as mulheres que vão ao sepulcro para ungir Jesus ( $\alpha$ 七ó $\nu$ ) (v.1) apresenta uma evidente ligação com aquilo que está narrado precedentemente. O pronome usado na expressão ungi-lo ( $\alpha$ vóo $\nu$ ) acena àquilo que foi dito antes sobre o cadáver de Jesus entregue a José (15,

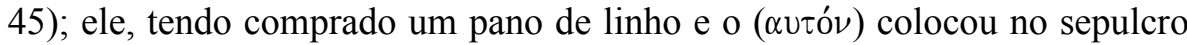
$(15,46)$. A chegada das mulheres ao sepulcro para ungir o cadáver de Jesus $(16,1)$ supõe que soubessem onde o tinham colocado; estas tinham estado presentes na cruz $(15,40)$ e tinham assistido a sua sepultura $(15,47)^{11}$. A perícope pode ser dividida da seguinte forma: parte introdutiva (vv.1-4) e aquela conclusiva (vv.7-8). Estas oferecem algumas dificuldades que são dirimidas somente na relação que possuem com a parte central (vv. 5-6).

$\mathrm{O}$ anjo é a personagem central. $\mathrm{O}$ evangelista fala de um jovem sentado à direita, vestido de branco. Mateus fala de anjo (Mt 28,5); Marcos mostra claramente. No Antigo Testamento se usa a imagem do jovem para designar um anjo: $2 \mathrm{Mc} 3,26$. 33-44; Tb 5, 5; 7,2; 8,1; 12,14. A sua veste branca indica que pertence ao mundo divino (Ap 6, 11; 7, 9; Mc 9,3) ${ }^{12}$. A posição do anjo sentado no lado direito introduz de modo adequado a mensagem que pronunciará. $\mathrm{O}$ estar sentado à direita manifesta a autoridade de portador de uma revelação ${ }^{13}$. As primeiras palavras são dirigidas diretamente às mulheres e tem o objetivo de dissipar o espanto das mulheres: Não vos espanteis (v.6). $\mathrm{O}$ anjo descreve a atitude das mulheres (v. 6b). O objeto imediato da busca das mulheres é a pessoa de Jesus, o Nazareno. Trata-se da figura de Jesus sem nenhum outro título de glória, somente com a denominação que tinha na sua vida mortal: o Nazareno (Mc 10,47); acrescenta-se: aquele que tinha sido crucificado. Assim, o anjo prepara a mensagem que está para anunciar.

O anúncio da ressurreição é o ponto central de todo o texto: Ressuscitou, não está mais aqui. Vede o lugar onde o puseram. Assim vem proclamada a ressurreição daquele que foi crucificado. Com estas palavras do anjo, anuncia-se o mesmo anúncio kerygmático dos apóstolos que anunciam: Jesus, $o$ Nazareno, que vós crucificastes Deus o ressuscitou dos mortos (At 4,10). O

\footnotetext{
${ }^{11}$ PESCH, R. Il vangelo di Marco. Parte Seconda. Brescia: Paideia Editrice, 1980, pp. 757-758. ${ }^{12}$ GNILKA, J. El Evangelio segun san Marcos. Volume II. Salamanca: Ediciones Sigueme, 1996, p. 401.

${ }^{13} \mathrm{PESCH}, \mathrm{R}$. Il vangelo di Marco. Parte Seconda, p. 775.
} 
anjo deixa entrever a ação mesma de Deus que ressuscitou Jesus, o uso do passivo divino ( $\left.\eta \gamma^{\prime} \in \theta \eta \eta\right)$ implica a intervenção de Deus na ressurreição de Jesus. O tempo passivo representa um momento concreto no qual Jesus crucificado, superando a morte, participa de uma existência nova. Coligado com o anúncio da ressurreição, fala-se da sua ausência do sepulcro: não está mais aqui. A sepultura está aberta porque Jesus está ressuscitado ${ }^{14}$. A ressurreição vem apresentada como um abandono do túmulo e não se indica somente a ausência de um cadáver, mas a inteira pessoa, isto é, daquele Jesus de Nazaré que foi crucificado, aquele que as mulheres procuravam. O tema do sepulcro vazio é mais desenvolvido no segundo Evangelho, onde não se desenvolve somente o fato da ausência de Jesus: as mulheres são convidadas a olhar o lugar onde ele tinha sido depositado. Mostrar o lugar, depois de ter proclamado a ressurreição, tem um significado especial porque em qualquer modo se unem assim, o tema da ressurreição e aquele do sepulcro vazio. Aqui a ligação é certamente mínima, trata-se de uma simples aproximação dos dois temas. J. GNILKA comenta que o túmulo vazio não tomou o foco da fé pascal, más ao contrário, é uma conseqüência da fé pascal, que se fundamenta na aparição do Ressuscitado. No horizonte da antropologia bíblica judaica, a expressão implica o túmulo vazio e pode-se pensar com pleno sentido a ressurreição só se se inclui a corporeidade ${ }^{15}$. R. PESCH diz que não se pode considerar historicamente verificável a descoberta do túmulo aberto e vazio por parte das mulheres no primeiro dia depois da crucificação e sepultamento de Jesus (p. 782s) ${ }^{16}$. E. SCHELLEBEECKX propõe que a tradição do sepulcro vazio iniciou em Jerusalém de lenda cúltica etiológica, isto é, para explicar por que haviam pessoas que faziam vigílias em Jerusalém junto ao túmulo considerado como sendo de Jesus. A história do túmulo vazio explicaria por que as pessoas se reuniam ali para rezar e cantar ${ }^{17}$. JAMES D. G. DunN mostra a tradição no judaísmo, como em outras culturas de venerar a memória dos mortos construindo sepulturas adequadas, mas que não há a mínima referência à veneração do túmulo de Jesus. Há fortes indícios de que o movimento de Jesus decolou em Jerusalém

\footnotetext{
${ }^{14} \mathrm{PESCH}$, R. Il vangelo di Marco. Parte Seconda, p. 777; Pesch, na página 781, quando faz um juízo sobre a historicidade do antigo texto conclusivo da história pré-marciana da paixão, afirma que o dado histórico decisivo que determina a composição da narrativa é a fé da Igreja primitiva na ressurreição corpórea de Jesus.

${ }^{15}$ GNILKA, J. El Evangelio segun san Marcos. Volume II, p. 401.

${ }^{16} \mathrm{PESCH}$, R. Il vangelo di Marco. Parte Seconda, p. 782s.

${ }^{17}$ SCHELLEBEECKX, E. Jesus: an Experiment in Christology. London: Bloomsbury T\&T Clarck, 1979.
} 
pouco tempo após a sua morte e desde o início o coração do anúncio foi a ressurreição de Jesus e não uma reproposição do seu anúncio. Não houve excessiva atenção por que o seu sepulcro era vazio, Jesus não tinha permanecido no sepulcro ${ }^{18}$. De certo modo, o sepulcro vazio orienta para o acontecimento da ressurreição. Oferecer um sinal, que de qualquer modo serve de apoio a um anúncio (Gn 18,14; Ex 3,12; Is 7,11-14; Lc 1,20.36; 2,12), é um procedimento frequente na comunicação que Deus faz aos homens através de um enviado especial.

$\mathrm{O}$ encargo às mulheres encerra as palavras do anjo: "Mas ide dizer aos seus discípulos e a Pedro que ele vos precede na Galiléia. Lá o vereis como vos tinha dito" (v.7). O preanuncio da aparição aos discípulos ajuda a garantir mais a proclamação sobre a ressurreição. Assim se completa o esquema do credo primitivo da primeira comunidade cristã (1Cor 15, 3-8). Depois de ter acenado à crucifixão, ao sepulcro vazio e a ressurreição, conclui com uma palavra do anjo, com o tema da aparição de Jesus. O conteúdo do encargo dado às mulheres consiste em comunicar aos discípulos qualquer coisa que já estava predito (Mc 14,28). As palavras do anjo dão especial relevo a Pedro. Pode ser pela questão da negação durante a Paixão, pode ser por causa da função especial exercitada por Pedro, desde o início na comunidade apostólica. A aparição pessoal a Pedro é um dado muito repetido na tradição (1Cor 15,3; Lc 24,34).

Tanto Pedro como os apóstolos devem dirigir-se para a Galiléia, onde Jesus os precederá. A presença de Jesus na Galiléia é expressa com um sentido de imediatez por meio do presente: ...ele vos precede na Galiléia $(16,7)$ $(\pi \rho \circ \alpha ́ \gamma \in \iota)$. Jesus antecipará os discípulos na Galiléia. O fato de mencionar a Galiléia no texto de Marcos parece ter um significado teológico concreto. Recorda o início do ministério de Jesus (Mc 1,14): a evangelização tinha começado na Galiléia antes da ressurreição e lá será recomeçada depois desta. $\mathrm{Na}$ Galiléia os discípulos verão (’o $\psi \epsilon \sigma \theta \epsilon)$ Jesus, como ele tinha antecipado $(14,28)$. Marcos usa aqui o verbo ver como tinha sucedido com freqüência nas tradições (Mt 28,10; Lc 24,34; 1Cor 15,5-8) para acenar às aparições de Jesus. Na Galiléia Jesus si manifestará aos discípulos. Só com o preanúncio da aparição se completa o credo primitivo na mensagem central do texto de Marcos transmitida pelo anjo: crucifixão, sepultura, ressurreição e aparição.

\footnotetext{
${ }^{18}$ DUNN, J. D. G. Gli albori del cristianesimo. La memória di Gesù. Volume 3. L 'acme della missione di Gesù. Brescia: Paidéia Editrice, 2007, pp. 888-892.
} 


\section{Narrativas da ressurreição em Mateus}

$\mathrm{Na}$ narração de Mateus se fundem diversas tradições: uma comum a Marcos (1,5-8), outra própria do primeiro evangelho (v.9-10) e a presença dos guardas no sepulcro $(27,62-66 ; 28,2-4)^{19}$. Nestas diversas tradições, as mulheres têm uma função mais complexa que em Marcos; elas têm uma importância tão grande, que gozam de um encontro com o ressuscitado. $\mathrm{O}$ contraste entre as mulheres e os guardas é somente de Mateus (v.1) e o motivo da visita ao sepulcro é somente para ver o sepulcro. A reação dos guardas e das mulheres: os guardas tremeram de medo e ficaram como que mortos (v.4), enquanto as mulheres não deixam que o temor se apodere delas e o anjo as exorta a superar o medo (v.5). O resultado será que a alegria os preenche no retorno ao sepulcro (v.8). As mulheres devem colocar os discípulos em contato com o ressuscitado.

Mateus, através do anúncio da ressurreição transmitido pelas mulheres, apresentará a ação futura dos apóstolos: eles falarão fazendo eco à mensagem do anjo descido do céu. A missão dada às mulheres prossegue numa outra cena: a aparição de Jesus a elas (v. 9-10). Jesus chama os discípulos: meus irmãos (v.10). Esta denominação não é usada pelo anjo quando se dirige às mulheres (v.7), porém a encontramos em Jo 20,17. A denominação dos discípulos como meus irmãos, já se encontram no primeiro Evangelho $(12,49)$, sem a necessidade de ver uma influência de um no outro. $\mathrm{O}$ ato de abraçar os pés é manifestação de alegria, já expresso antes (v.8); é um modo natural de exprimir a alegria de revê-lo (2Rs 4,27). O ato de adoração (v. 9) se repetirá na aparição aos discípulos sobre o monte na Galiléia (v.17). Ainda que não haja motivo para falar de um contato entre as fontes, é possível dizer que as duas narrações acenam para o mesmo fato: a aparição de Jesus a Madalena. As diferenças não impedem a identidade do fato. Na narração de Mateus, Jesus aparece a diversas mulheres (v.9); na de João, somente para a Madalena. O plural usado por Mateus é o prolongamento dos dois nomes mencionados antes (v.1) referindo-se a um personagem concreto. Não é raro Mateus falar de uma categoria de pessoa acenando a uma só (Mt 27,44; Lc 23,39). Na mensagem de Mateus para os discípulos se fala de dirigir-se para a Galiléia (v.10),

\footnotetext{
${ }^{19}$ TRILling, W. O anúncio de Cristo nos Evangelhos sinóticos. São Paulo: Paulina, 1981, pp. 193ss; GNILKA, J. Il vangelo di Mateo. Parte Seconda. Bréscia: Paideia Editrice, 1991, p. 716, comenta que com relação a Mc 16, 1-8 se encontra notáveis mudanças. Mateus deu ao texto uma forma nova.
} 
enquanto João afirma que Jesus ainda não subiu ao Pai (Jo 20,17). Assim a versão de João é mais teológica que histórica, mais pessoal que tradicional. Para João, no mesmo dia da ressurreição acontece o Pentecostes (20,21-23) e a ascensão, ignorada pelos outros evangelistas. A diferença de lugares, segundo João, junto ao sepulcro e para Mateus, no retorno deste, não representa um obstáculo para a identificação do fato. A diferença topográfica pode ser atribuída às perspectivas diversas dos autores. Mateus afasta a aparição do anjo daquela de Jesus. A narração da aparição de Jesus às mulheres em Mateus (v. 9-10) é então um resumo que chegou até o evangelista de uma fonte diversa daquela de João $(20,11-18)$. As duas fontes transmitem, de modo diverso, a mesma aparição de Jesus a Maria Madalena. Consequentemente, as mulheres adquirem um maior relevo, que não nos outros evangelistas. No primeiro evangelho assistem à derrota dos guardas e servem para unir os discípulos ao mestre, e por primeiro são participantes do encontro com o ressuscitado.

O evangelista enfrenta a questão da mentira espalhada pelos judeus, esta mentira chegou até o tempo do evangelista (Mt 28,15). O evangelista dá importância ao túmulo vazio, mas este permanece um sinal, pois este podia ter uma interpretação equivocada. Falar da ressurreição, tem sentido somente se esta é concebida como ressurreição do corpo, seja mediante a nova criação, seja mediante a restituição criativa do corpo de Jesus ${ }^{20}$. A comunicação da mensagem do anjo pelas mulheres apoia-se sobre o encargo que o anjo, descido do céu, tinha dado: Ide contar aos discípulos que ele ressuscitou dos mortos. A garantia da mensagem é confirmada pelo preanúncio de um encontro pessoal dos discípulos com o ressuscitado na Galiléia. W. TRILling comenta: "Na mensagem do anjo, Mateus deslocou a tônica. Também em Marcos todo o texto já tem o escopo de fazer emergir o conteúdo do anúncio do sepulcro vazio. Esse fato já deve expressar, por si, a ressurreição do Crucificado. Sabemos (sobretudo por 1 Cor 15, 3-8) que a fé pascal dos discípulos se fundou nas aparições do ressuscitado. O sepulcro vazio pôde, então, ser claramente compreendido a partir da fé no anúncio da ressurreição de Jesus. A isso corresponde uma possível reconstrução histórica, que em todo caso pode fazer seguro ou verossímel o fato de o sepulcro de Jesus ter sido achado vazio"21. J. GNILKA comenta que ainda que Mateus coloque o acento de maneira marcante sobre o túmulo vazio, o kerygma permanece indispensável. ${ }^{22} \mathrm{O}$ orientamento

${ }^{20}$ GNILKA, J. Il vangelo di Mateo. Parte Seconda, p. 723.

${ }^{21}$ TRILLING, W. O anúncio de Cristo nos Evangelhos sinóticos, p. 198.

${ }^{22}$ GNILKA, J. Il vangelo di Mateo. Parte Seconda, p. 720. 
teológico desta primeira parte do Evangelho é forte. É uma grande vitória de Deus; prevalece a força vinda do alto. Os diversos aspectos da sua descrição falam de um triunfo de Deus mesmo. Aquele que desce do céu é o anjo do Senhor (v.2). O esplendor do seu aspecto e a candura das suas vestes mostram um personagem celeste (v.3); o terremoto é sinal da teofania (v.2) ${ }^{23}$. A presença e ação de Deus são manifestadas com o uso do passivo divino (v.6-7): Deus mesmo o ressuscitou. Esta vitória não é descrita como somente de Deus, o triunfo é também de Jesus. O Evangelista uniu expressamente o Jesus crucificado, cercado pelas mulheres, ao ressuscitado (v.5). A crucifixão se transforma em ressurreição, Jesus mesmo já tinha preanunciado o seu triunfo final. A cruz perde assim a cor da ignomínia para ter a luz da glória. Também os discípulos de Jesus participam desta vitória. Os discípulos, na nova dimensão de irmãos de Jesus (v.10), são participantes da morte do mestre. Por isso, vem comunicado a eles não somente o acontecimento da ressurreição, segundo a pregação de Jesus (v.6), mas a alegria de um encontro com ele na Galiléia (v.7). O Evangelista, através deste encontro na Galiléia, confere à vitória da ressurreição uma dimensão de universalidade. A Galiléia é para Mateus o lugar onde, para aqueles que habitavam na região da morte, levanta uma luz (Mt 4,6). Mateus chama Galiléia dos gentios (Mt 4,15). A menção da Galiléia, falando da aparição de Jesus aos discípulos, deixa ver a luz de que gozam todas as gentes no participar do mesmo triunfo da ressurreição de Jesus. O crucificado, após a morte, ressuscita; serão os guardas mesmos que permanecerão como que mortos pela presença do anjo (v.4). A expressão mais plástica da derrota da morte é a posição do anjo sentado sobre a pedra do sepulcro. $\mathrm{O}$ anjo rola a pedra e a morte vem derrotada.

O evangelista estabelece com a sua mensagem o início de uma época de tempos novos. Inaugurando um período novo, a ressurreição de Jesus é assinalada por um significado escatológico. Com o terremoto, o anjo, mediante estas imagens apocalípticas, Mateus mostra que algo novo é começado. Aquele que foi crucificado inaugura uma vida nova (v.7). Com o conhecimento desta novidade, as mulheres se enchem de alegria (v.8). Na nova condição de irmãos de Jesus (v.10), os discípulos são convidados a encontrar-se com o ressusci-

\footnotetext{
${ }^{23}$ Os elementos da teofania, distribuídos segundo um esquema mais ou menos complexo, se encontram ao longo de toda a tradição bíblica: terremoto (Ex 19,18; 1Rs 19, 12; S1 114, 7); a veste branca como a neve (Dn 7,9) o aspecto glorioso (Dn 10, 6). Cf. FABRIS, R. Matteo. Traduzione e comento. Roma: Borla, 1982, p. 563, n. 2.
} 
tado (v.7). A ressurreição leva, então, à inauguração de uma nova etapa para Jesus, para as mulheres e para os discípulos.

$\mathrm{Na}$ aparição de Jesus na Galiléia narrada em Mt 28, 16-20 vem indicada uma nota topográfica que não se encontra nas diversas tradições (v.7.10). Os discípulos se encaminham para a Galiléia, para um monte (v.16). O monte é um lugar frequente da revelação e manifestação de Deus no Antigo Testamento (Ex 3, 1-2; 19, 3-25). Mateus usa também o monte na Galiléia como lugar da promulgação do programa do reino (Mt 5,1) e da transfiguração (Mt 17,1). Isto que acontecerá nesta aparição de Jesus na Galiléia, vem enquadrado na modalidade de revelação. O conteúdo mesmo que Jesus dirige aos discípulos o confirma. Na revelação, há a manifestação de Deus como origem de todo poder. Também a vitória revelada antes provém dele. O uso do "passivo divino" nas palavras do ressuscitado: Toda autoridade sobre o céu e sobre a terra me

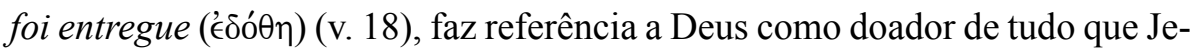
sus possui. O poder ilimitado de Deus, expresso pelo termo $€ \xi$ ovoí $\alpha$ (Sir 10,4) foi concedido totalmente a Jesus: $\pi \hat{\alpha} \alpha \sigma{ }^{\natural} \zeta \zeta$ ovoí $\alpha$. O domínio de Jesus se torna universal porque se estende a todo o mundo: céu e terra. Tudo tem o seu ponto de partida na nova situação em que se encontra Jesus como ressuscitado.

O poder de Jesus se repercute sobre os discípulos. São enviados a todos os povos em missão de fazer todos discípulos de Jesus. Deste modo, eles se fazem participantes da vitória de Jesus; recebem o poder e a missão de Jesus de "fazer discípulos". Aqueles que se convertem em discípulos mediante o batismo e o ensinamento do Mestre participam também da vitória de Jesus. Como os apóstolos, aqueles que se fazem discípulos poderão ser chamados irmãos do ressuscitado, conquistarão uma nova posição que os fará participantes da vida e da vitória de Jesus. Na primeira parte se liga o Jesus crucificado com o ressuscitado (v.5-6): há uma linha de continuidade entre estes dois aspectos. Também aqui se apresenta esta linha de continuidade entre o Jesus terreno e o ressuscitado. Jesus ressuscitado que aparece aos onze confirma o ensinamento que tinha transmitido quando vivia com eles (v.20). Na continuidade se sublinha a diferença. Na sua vida terrena, Jesus tinha dito que o Pai lhe tinha dado tudo (Mt 11,27). Este tudo, nesta frase de Jesus, se explica em função do conhecimento do Pai e também da transmissão deste conhecimento aos quais Jesus queria revelar. $\mathrm{Na}$ cena da aparição aos discípulos se fala de um poder absoluto dado a Jesus. Duas formas expressam este poder: toda autoridade e uma outra que manifesta universalidade: céu e terra. A ressurreição, mesmo conservando uma continuidade com o Jesus terreno, sublinha uma nova etapa 
que inicia nele e com ele também para os apóstolos e discípulos. A nova etapa que se abre é assinalada não somente com do poder de Jesus, pela missão dos apóstolos e dos novos discípulos, mas também pela presença estimulante de Jesus. Ele promete que estará com os seus discípulos todos os dias. Trata-se de uma presença dinâmica que ajudará os apóstolos no cumprimento da missão que receberam para todos os povos.

\section{A Ressurreição na obra de Lucas: Lc 24, 1-53}

O texto de Lc 24, 1-12 é a parte mais semelhante aos outros sinóticos, com uma tradição comum a Mateus e a Marcos nas suas características fundamentais. Lucas mostra na sua redação uma grande liberdade no omitir alguns dados, no trocar outros e no acrescentar notas próprias, orientando para a preparação da teologia por ele desejada. E possível que a tradição em que se inspiraram Marcos, Mateus e Lucas dissessem somente que as mulheres foram ao túmulo e que os evangelistas tenham acrescentado os motivos para informar os seus leitores. Assim, João e os sinóticos não divergem tanto como poderia parecer $^{24}$. As mulheres, entrando no túmulo, não encontraram o corpo do Senhor Jesus. O túmulo vazio significava que Cristo tinha ressuscitado. A fórmula Senhor Jesus não aparece em todos os manuscritos importantes, mas poderia ser esta a lição original, porque, em Lucas, Jesus é regularmente chamado de Senhor: (Lc 7, 19; 10,1; 11,39; 12, 42; 17; 5 - narrações; Lc 2,10s; 19,31).

Os dois homens, com vestes fulgurantes, são evidentemente seres sobrenaturais: vestes fulgurantes ( $\operatorname{Lc} 9,29)$. O testemunho do anjo constitui o ponto central de toda a cena. $\mathrm{O}$ anjo acena como nos outros sinóticos ao sepulcro vazio: não está aqui e proclama a mesma mensagem da ressurreição de Jesus ${ }^{25}$.

${ }^{24}$ DUNN, J. D. G. Gli albori del cristianesimo. La memória di Gesù. Volume 3. L ‘acme della missione di Gesù, pp. 883-884. Mostra que este é um belíssimo exemplo do processo de formação e transmissão oral da tradição. Há um núcleo estável bem claro, ao redor deste núcleo estável a história é re-narrada de modo muito diverso. Estas variações se devem ao interesse específico de cada evangelista: Marcos deixa os seus ouvintes em suspense com as mulheres que não dizem nada a ninguém (Mc 16,8); Mateus insere a história dos guardas e acha oportuno inserir um segundo terremoto $(28,2)$; Lucas transforma a promessa de uma aparição na Galiléia $(16,7)$ em recordação de algo dito na Galiléia (Lc 24, 6-7); João dedica a sua atenção a Maria Madalena para preparar a aparição a Maria (Jo 20, 11-18).

${ }^{25}$ A ordem é aquela de Mateus, primeiro o sepulcro vazio depois a proclamação da ressurreição de Jesus. Lucas fornece duas testemunhas no sentido Judaico da palavra. Estas testemunhas são homens e são duas (LEON-DUFOUR, X. Risurrezione di Gesù e messaggio pasquale, p. 205). 
Lucas usa a partícula adversativa $\alpha \lambda \lambda \alpha$ para unir os temas do sepulcro vazio ao da ressurreição. O sepulcro vazio sem ser uma prova da ressurreição permanece um sinal; a ressurreição é corroborada com o não estar mais no túmulo ${ }^{26}$. As palavras pronunciadas constituem a nota mais característica de Lucas em toda esta narração: por que procurais Aquele que vive entre os mortos? Deste modo, a ressurreição vem explicada como vida; também depois da morte, Jesus é denominado "o vivente". Lucas aplica a Jesus uma expressão comum, que se diz de Deus nos Atos: Deus vivente (At 14,15). Deus que ressuscitou Jesus lhe comunicou uma vida especial. Esta vida venceu a morte, através da qual passou Jesus, que não pode mais ser encontrado entre os mortos.

Depois o evangelista menciona a Galiléia e relembra as palavras de Jesus (v. 6). Vem omitido o encargo das mulheres de transmitir aos discípulos que se encaminhem para a Galiléia. Assim, Lucas evita desviar as aparições de Jerusalém; menciona a Galiléia em perspectiva passada. Lucas não acena ao encontro com o ressuscitado, mas sintetiza tudo na recordação do que Jesus tinha dito. $\mathrm{O}$ ensinamento de Jesus é apresentado de forma solene pela boca do anjo: (v. 7). As mulheres são apresentadas assim como destinatárias diretas do ensinamento de Jesus. Lucas tinha mencionado as mulheres diversas vezes no calvário; agora cita os nomes $(23,49.55 ; 24.1 ; 24,10)$. Lucas não menciona nenhuma aparição às mulheres. Também os discípulos têm na narração de Lucas aspectos especiais. É ampliado o número; vêm mencionado outros que estão com os onze. A todos as mulheres contam o que tinham visto e ouvido (v. 9). Reserva aos onze o nome de apóstolos (v. 10). O ceticismo daqueles que escutaram as palavras é colocado em evidência por Lucas: julgam as pala-

${ }^{26}$ ROSSÉ, G. Il Vangelo di Luca. Commento esegetico e teológico. Roma: Città Nuova Editrice, 1995, p. 1005 diz: Benchè la tradizione non descriva com esatteza il fato storico, alla base della narrazione si trova um evento reale: la tomba di Gesù fu trovata vuota da parte di qualque donne. Gli argomenti a favore di questo núcleo storico sono sintetizzati da J. Kremer nei punti seguenti: la localizzazione della sepultura era conosciuta, ed era uso che alcune donne visitassero la tomba di um morto; la chiesa non avrebbe potuto "inventare" la scoperta della tomba vuota da parte delle donne, lê quali non erano giudicate testimoni affidabili; la tumba vuota no fu contestata dagli avversari, ma solo diversamente interpretata; 1'indicazione "il primo giorno della setimana" è um ricordo storico; Maria di Magdala era sens altro conosciuta nella Chiesa primitiva: dicerie sul suo conto da parte di uma tradizione arca'ca (come quella sulla tomba vuota) poteva essere verificate e smentite (KREMER, J. "Zur Diskussion uber 'das leere Grab'”. In: DHANIS, É. (Ed.). Resurrexit. Vaticana: Editrice Libreria, 1954, p. 157). SABOURIN, L., S.J Il Vangelo di Luca. Introduzione e Comento. Roma / Casale Monferrato: Gregoriana / Piemme, 1989, p. 366 comenta que para Lucas e a Igreja primitiva o túmulo vazio significava que Cristo tinha ressuscitado. 
vras fantasia e não dão crédito. Lucas coloca assim, em contraste as mulheres com os apóstolos. Ele assume uma orientação apologética. As testemunhas da ressurreição em Lucas permanecem independentes delas.

A narração de Emaús (Lc 24,13-35) se apresenta não tanto como uma cena de aparição, mas de reconhecimento. Não interessa a aparição mesma; Jesus, uma vez que foi reconhecido, desaparece. O interesse recai sobre a descoberta da pessoa mesma de Jesus num personagem que no início se apresenta desconhecido. Esta cena foi comparada àquela da aparição de Jesus a Maria Madalena (Jo 20, 11-18). Em ambas, Jesus se apresenta de uma forma que o vela: aqui, como peregrino (Lc 24, 15); e na outra, como jardineiro (Jo 20,15). O início das duas cenas é envolvido por uma atmosfera de depressão psicológica, tristeza dos discípulos de Emaús (Lc 24,17) e lágrimas de Maria Madalena. O momento culminante nas duas narrações é o reconhecimento de Jesus na figura do peregrino ao partir do pão ( $\operatorname{~c~24,30-~}$ 31 ) e na pessoa do jardineiro, quando pronuncia o nome de Maria (Jo 20,16). Porém, reconhecido, Jesus desaparece da vista dos discípulos (Lc 24,31) e a Maria Madalena vem proibido de continuar na sua atitude estática para ir comunicar algo aos discípulos (Jo 20,17). Depois do reconhecimento muda o comportamento dos protagonistas: os discípulos sentem arder o coração (Lc 24,32) e vão comunicar aos onze (Lc 24,35); Maria Madalena, consolada no seu choro, vai transmitir aos discípulos quanto o Senhor lhe tinha dito (Jo 20,18). É presente nesta narração a fé da primeira Igreja no confessar a aparição de Jesus a Pedro (v. 34; 1Cor 15,5).

Os versículos 36 a 53 constituem a última parte do capítulo final do terceiro Evangelho. Apresenta diferenças com a narração anterior: lá os discípulos se mostravam seguros (v. 34). Aqui, agem de modo vacilante, cheios de temor e crêem ver um fantasma (v. 37-38). Porém, o evangelista tenta fazer esta ligação com a narração anterior através das palavras introdutórias: " falavam ainda..." (v. 36a; cfr. Vv. 34-35).

Toda esta última parte (36-37) constitui uma unidade. Abre-se com a expressão: Falavam ainda $\left(36^{\text {a }}\right.$; Cfr At 4,$\left.1 ; 10,44\right)$. Prossegue com o primeiro ato (36b). Esta idéia e a sua formulação verbal se coliga com todo o resto: "e enquanto os abençoava se separou deles..”. No final se fala novamente dos discípulos, narrando o retorno deles para Jerusalém e a permanência no Templo, louvando a Deus (v. 52-53). Com o aceno aos discípulos se abria a cena (v.36). Toda a narração é o agir de Jesus que assinala o início dos diversos estágios da cena: Jesus em pessoa aparece no meio deles (v.36), depois lhes disse (v. 44), 
“depois os levou até Betânia" (v. 50). Os discípulos aparecem mediante o uso dos pronomes (vv. 36. 38. 41. 43. 44. 45. 50. 51. 52).

Todo o capítulo é enquadrado no mesmo dia. Colocando tudo no dia de Páscoa, Lucas não quer oferecer uma cronologia das aparições, mas apresentar um sentido unitário, à luz da ressurreição, a luz da fé e o conteúdo da mensagem.

$\mathrm{Na}$ cena de reconhecimento dos versículos 36 a 42, a atitude dos discípulos cheios de espanto e temor no início (v. 37) se transforma em alegria no fim (v. 41). Uma evolução semelhante àquela dos discípulos de Emaús como conseqüência da conversa com Jesus: a tristeza inicial (v. 17), que os fez afastarem-se dos onze, muda em entusiasmo que os faz retornar para narrar ao grupo aquilo que aconteceu (v. 32-33). Na cena do cenáculo, a alegria depois da superação da dúvida que assaltava os discípulos (v. 38). O fato de sublinhar que a dúvida foi superada, supõe um objetivo apologético: mostrar assim, as testemunhas oficiais da ressurreição não como vítimas de um entusiasmo passageiro, mas convencidos de sua experiência. Esta pode ainda responder à necessidade da primeira comunidade na qual se proclamava a ressurreição de Jesus. Todavia, não se pode afirmar que esta dúvida seja do cristianismo helênico.

Os apóstolos vencem a dúvida graças à manifestação de Jesus mesmo, apresentando-se diante deles (v. 39). O objetivo é que os discípulos o reconheçam na sua identidade corpórea. Aqui não se pretende que o distingam de outros personagens, mas se pretende que o distingam de um espírito, de um fantasma, daquilo que crêem ver (v. 37). O reconhecimento de Jesus, neste caso, consiste no reconhecimento da sua realidade física por parte dos discípulos. Isto explica a insistência no mostrar as mãos e os pés (vv. 39-40). Chega a tal ponto a importância da sua corporeidade, que os discípulos chegam a tocar as suas mãos (v. 39) e a comer com eles (v.43).

Esta realidade física, mesmo sendo o meio de reconhecimento, tem uma importância secundária com relação à intenção primeira do evangelista. A realidade física nem o comer são apresentados como prova da ressurreição. Tudo tende a sustentar a experiência objetiva dos discípulos, de modo que esta os converta em testemunhas, garantes da mensagem que vão proclamar. No livro dos Atos se acena a esta experiência para assegurar a credibilidade das testemunhas (At 1,4;10,41). O significado de todos estes dados corpóreos não se limita a sua dimensão apologética. Eles revestem também um valor e um conteúdo teológico porque, sem materializar a ressurreição, contribuem a 
ressaltar o seu mistério. De uma parte há uma continuidade entre Jesus que viveu com os discípulos; de outra, a inesperada presença no meio deles supera esta continuidade com a sua nova corporeidade. Podem também ser meios capazes de exprimir a nova vida que tem o ressuscitado e um sinal de alegria (Lc 15,23-24) pela participação no banquete do reino (Lc 22,16).

Os versículos 44 a 49 se estruturam em duas seções diversas, mas complementares. A primeira reflete um caráter próprio de Lucas (vv.44-45); a segunda, ainda com características de Lucas, faz eco a uma tradição comum com os outros evangelhos (vv.46-49). O conjunto das duas seções oferece um rico conteúdo como síntese de um passado e programa de um futuro. Os versículos 44-45 fazem eco, em primeiro lugar, às palavras de Jesus durante a sua vida com os apóstolos, com as quais acenava ao cumprimento das Escrituras em tudo aquilo que se referia a Ele. É um tema presente em todo o Evangelho. Na sinagoga de Nazaré (Lc 4, 21); as predições da paixão (Lc 9,27; 17, 25); terceiro anúncio da paixão (Lc 18,31-33). O diálogo com Moisés e Elias durante a transfiguração falam sobre o êxodo de Jesus ( $\operatorname{cc} 9,31)$. Na última ceia, afirma que é preciso que se cumpra nele aquilo que está escrito (Lc 22,37). Estes ensinamentos vêm comunicados com termos muito semelhantes aos dos discípulos de Emaús (Lc 24, 26-27). Esta seção ilumina os discípulos não só com a exegese feita por Jesus, mas também pela luz mesma do acontecimento da ressurreição (v. 45). A falta desta inteligência das Escrituras tinha caracterizado a atitude dos discípulos (Lc 9,$45 ; 18,34)$. Agora, a experiência pascal da ressurreição abre a mente a fim de que compreendam o significado das Escrituras (At 3, 17-18; 17, 3).

Os versículos 46 a 49 retomam de novo o ensinamento da Sagrada Escritura para o que se refere à morte e ressurreição de Cristo (v.46). Na formulação do evangelista (v.46) vem dada uma cópia do credo primitivo (1Cor 15, 3-4) e da pregação dos apóstolos (At 17,3); são indicadas também, junto com o credo, a pregação no seu nome e a conversão para a remissão dos pecados; tudo isto começando por Jerusalém (47). Assim, o programa descrito no livro dos Atos vem ancorado pela Escritura mesma. Junto com o tema da crucifixão e da exaltação de Jesus, os discípulos falam do perdão dos pecados. Assim, eles apresentam como conteúdo do credo: "morreu pelos nossos pecados (1Cor 15, 3); convertem-no em objeto da pregação (At 5, 30-31; 10, 39-43). Os apóstolos começaram toda esta atividade em Jerusalém (At 1,8; 2,5.14; 6,7 ), levando esta mensagem de salvação a todos os povos (At 1,8; 8, 4-5; 11, $1 ; 28,28)$. Este programa teve início no ministério de Jesus. Assim, como nele 
são cumpridas a morte e a ressurreição predita nas Escrituras, é sempre ele que inicia a pregação da conversão $(5,32)$ para a remissão dos pecados. Jerusalém ocupa um lugar central no Evangelho, lugar onde chega à plenitude a obra da salvação $(9,31)$ e da qual se estenderá a todos os povos. Todos os povos são presente no seu orientamento universal $(2,31-32 ; 3,6)$. O último elemento é a missão apostólica que Jesus dá aos discípulos. Estes devem ser testemunhas de tudo isto (v. 48). Liga-se o fim do evangelho com o início e desenvolvimento de Atos $(1,8 ; 2,32 ; 3,15 ; 5,32 ; 10,39)$. O objeto do testemunho vem descrito de forma genérica: vós sereis testemunhas disso (v. 48). Nesta expressão está compreendido todo o acontecido antes: as palavras e os ensinamentos de Jesus quando estava com eles (v. 44) e aquilo que foi predito pelas escrituras como Jesus os fez compreender através da luz do acontecimento pascal (v. 45).

Para cumprir esta missão, os apóstolos contam com o envio que Jesus fará da promessa do Pai (v. 49). Por Jesus, o Pai tinha prometido a efusão do Espírito Santo. Glorificado, Jesus levou a cumprimento esta promessa (At 2,33 ). Os discípulos já tinham escutado de Jesus esta promessa quando viviam com ele (At 1,4; Jo 15,26). Deviam permanecer na cidade até serem revestidos pela força do alto (v. 49). Esta força ajudará a cumprir a missão (At 1,18). O Espírito prometido contribuirá também para uma maior inteligência das palavras que Jesus tinha comunicado precedentemente aos discípulos (Lc 24, 44). Com a ajuda do Espírito, os apóstolos poderão conduzir a missão a eles confiada.

\section{Algumas conclusões}

1. Os relatos narram elementos históricos, alguns já elaborados com uma finalidade catequética, kerygmática; e outros, contendo elementos apologéticos mediante questões que começam a surgir. Os elementos diferem nas narrações devido às tradições diversas do mesmo relato.

2. Todos os Evangelistas atestam a realidade do sepulcro vazio. Segundo a mentalidade e a antropologia judaica, seria impossível falar da ressurreição sem que o ressuscitado tivesse saído do sepulcro ${ }^{27}$. Há indícios que levam à afirmação de uma ligação entre o anúncio do

${ }^{27}$ KREMER, J. Das Zeugnis, p. 3; RIGAUX, B. Dieu l'a ressuscitè, p. 123; DÍEZ MACHO, A. La resurreccion de Jesucristo, p. 270. 
kerygma e o túmulo vazio (1Cor15, 4; At 2,29; At 13, 29). A historicidade do sepulcro vazio é dificilmente eliminável. A descoberta do sepulcro vazio é explicitamente presente nos quatro Evangelhos. Alguns elementos corroboram esta afirmação: a impossibilidade de proclamar a ressurreição em Jerusalém, se o túmulo não estivesse vazio; a própria polêmica judaica do furto do cadáver supõe o sepulcro vazio. O sepulcro vazio é um canal de união entre o crucificado e as aparições do ressuscitado.

3. Os relatos das aparições mostram uma identidade entre o Jesus histórico e o ressuscitado. Trata-se de testemunhos valiosos, recebidos de tradições diversas. É errado reduzir a experiência pascal a simples alucinação, porque é com base nelas que se move de modo histórico extraordinário o empenho missionário dos discípulos, concluindo até com o martírio. Os textos mostram um movimento das aparições a uma função comunitária: o caso de Paulo; porém, há beneficiários das cristofanias que não exercitaram função missionária (como as mulheres e os discípulos de Emaús).

4. A corporeidade de Jesus não pode ser entendida como um puro e simples retornar à vida terrena. A ressurreição de Jesus não é como aquela do filho da viúva de Naim e de Talita. Esta não consiste numa mera reativação ou reanimação de um cadáver. Deve-se observar: os contatos do ressuscitado com os destinatários da sua aparição são temporários, não constituem e não caracterizam os de uma vida "histórica": se fala de "aparição" (do verbo grego empregado em 1Cor

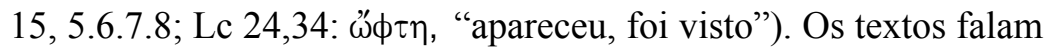

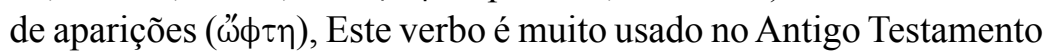
na LXX (Gn 12,7; Gn 18,1; 26, 2.26; Gn 35,9; Ex 3,2.6) e no Novo Testamento (Lc 1,11; Lc 22, 43; Mt 17,3; Mc 9,4; At 13,31; 26,16; Lc 24,34). O verbo usado na voz média mostra que é Cristo que aparece, manifesta-Se. A iniciativa é Dele. Nas aparições, é Cristo ressuscitado mesmo que desvela a sua nova forma para comunicarse com aqueles aos quais se mostra. A corporeidade de Jesus não pode ser entendida como um puro e simples retornar à vida terrena. A ressurreição de Jesus não consiste num mero reavivamento de um cadáver. Seu corpo não é mais físico, mas pneumatikon, espiritual, então inacessível ao homem na sua realidade íntima (1Cor 15,44). 
A natureza destas aparições foge às nossas categorias. De uma parte não se trata de algo meramente subjetivo, de visões subjetivas. Nas aparições entra em jogo o encontro com o ressuscitado, colocado numa linha de continuidade com Aquele que morreu e foi sepultado (Mc 16,6; Mt 28,5). Não se trata de uma visão meramente sensível como aquela de qualquer outro corpo. Encontramos-nos com uma forma paradoxal de falar, na qual convergem elementos desiguais, como a revelação que provém em última instância de Deus e a percepção corporal de algo que supera a capacidade mesma da visão humana.

5. Se devemos falar de milagres, este não foi operado por qualquer taumaturgo, mas por Deus mesmo.

6. Por isso, a ressurreição de Jesus não se coloca no interno da história à maneira de qualquer prodígio, mas vem percebida como um extraordinário evento escatológico, denso de consequências, não só para Jesus, mas, sobretudo para os homens em geral (a ressurreição dos mortos em Mt 27,52-53; a frase de At 4,2: "Anunciavam em Jesus a ressurreição dos mortos"; e a pregação aos mortos em 1Pd $3,19)$, tanto que Paulo fala de «primícias» (1Cor 15,23). Esta realidade, sem paralelo, vem definida pelo apóstolo como "corpo pneumático" (1Cor 15,42-47), isto é, como uma existência totalmente impregnada pelo Pneuma, do Espírito de Deus, ou analogamente como "corpo glorioso" (Fl 3,21).

Certo é que as aparições do Ressuscitado não vêm apresentadas como um arrebatamento estático e muito menos como visão irreal, mas no contexto de uma normal e concreta experiência humana. Os dois dados das cristofanias pascais e do testemunho daqueles que se beneficiaram, conexos, conservam uma irrepetível dimensão de fundamento histórico da fé da Igreja ${ }^{28}$.

${ }^{28}$ KENDALL, D.; O'COLLINS, G. "The Uniqueness of the Easter Appearances". $C B Q$ 54(1992), pp. 287-307; PENNA, R. I ritratti originali di Gesù il Cristo. Gli inizi. Volume 1. Cinisello Balsamo (Milano): Edizioni San Paolo, 1996, p. 188. 


\section{Referências bibliográficas}

CABA, J. Cristo mia speranza è risorto. Cinisello Balsamo: Edizioni Paoline, 1988.

DÍEZ MACHO, A. La resurreccion de Jesucristo y la del hombre en la Biblia. Madrid: Editorial Fondacion Ross, 1977.

DUNN, J. D. G. Gli albori del cristianesimo. La memória di Gesù. Volume 3. L 'acme della missione di Gesù. Brescia: Paidéia Editrice, 2007.

EYZAGUIRRE, S. F. Jesùs. Los orígenes históricas del cristianismo: desde el año 28 al 48 d.c. Santiago: Ediciones Universidad Católica de Chile, 2007.

FABRIS, R. Matteo. Traduzione e comento. Roma: Borla, 1982.

FABRIS, R. Prima Lettera ai Corinzi. Milano: Paoline, 1999.

GNILKA, J. El Evangelio segun san Marcos. Volume II. Salamanca: Ediciones Sigueme, 1996.

GNILKA, J. Il vangelo di Mateo. Parte Seconda. Bréscia: Paideia Editrice, 1991.

KENDALL, D.; O'COLLINS, G. "The Uniqueness of the Easter Appearances". CBQ 54 (1992), pp. 287-307.

KREMER, J. Das älteste Zeugnis Von der Auferstehung Christi. Eine bibeltheologische Studie zur Aussage und Bedeutung Von 1Kor 15, 1 - 11. Volume 17. Katholisches Bibelwerk: Stuttgart, 1966.

KREMER, J. “Zur Diskussion uber 'das leere Grab”". In: DHANIS, É (Ed.). Resurrexit. Vaticana: Editrice Libreria, 1974.

LÉON-DUFOUR, X. Risurrezione di Gesù e messaggio Pasquale. Cinisello Bolsamo (Milano): Edizione Paoline, 1987.

MARTINI, C. M. Il problema storico della risurrezione negli studi recenti. Roma: Universitá Gregoriana Editrice, 1980.

PENNA, R. I ritratti originali di Gesù il Cristo: Gli inizi. Volume 1. Cinisello Balsamo (Milano): Edizioni San Paolo, 1996.

PESCH, R. Il vangelo di Marco. Parte Seconda. Brescia: Paideia Editrice, 1980. 
RIGAUX, B. Dieu l'a ressuscite. Exégèse et théologie biblique. Gembloux: Duculot, 1973.

ROSSÉ, G. Il Vangelo di Luca. Commento esegetico e teológico. Roma: Città Nuova Editrice, 1995.

SABOURIN, L., S. J. Il Vangelo di Luca. Introduzione e Comento. Roma / Casale Monferrato: Gregoriana / Piemme, 1989.

SCHELLEBEECKX, E. Jesus: an Experiment in Christology. London: Bloomsbury T\&T Clarck, 1979.

STRAUSS, D. F. Das Leben Jesu kritisch bearbeitet. Volume II. Tübingen: Mohr, 1836.

THEISSEN, G.; MERZ, A. O Jesus histórico. Um manual. São Paulo: Edições Loyola, 2002.

TRILLING, W. O anúncio de Cristo nos Evangelhos sinóticos. São Paulo: Paulinas, 1981.

Dom Paulo Cezar Costa

Bispo da Diocese de São Carlos

Doutor em Teologia pela Pontifícia Universidade Gregoriana de Roma Professor do Departamento de Teologia na Pontifícia Universidade

Católica do Rio de Janeiro

Rio de Janeiro / RJ - Brasil

E-mail: paucosta@puc-rio.br

Recebido em: 20/09/16

Aprovado em: 13/10/16 